\title{
Poesia e memória
}

\author{
na obra do químico Primo Levi
}

\begin{abstract}
Resumo
Primo Levi escreve poesia ao longo da sua carreira de escritor. Contraria assim a afirmação do filósofo alemão, Theodore Adorno, que, após as revelações da verdadeira natureza dos campos de concentração nazis, concluíra que, a partir dessa data, seria impossível escrever poesia: o acto de escrever um poema parecer-Ihe-ia um desvio do olhar para com a barbárie que se instaurara na cultura ocidental. Levi, porém, publicará sessenta e um poemas durante a sua vida reunidos em duas colectâneas. Pelas datas atribuídas aos poemas, depreende-se que, embora de produção irregular e relativamente parca, a poesia acompanha 0 autor durante toda a sua vida adulta. 0 que significará o acto de escrever um poema para Levi? Qual
\end{abstract}

será a relação desta criação poética com Levi, o químico, e Levi, o sobrevivente de Auschwitz? As respostas e as dúvidas, i.e., os diálogos que, como cientista, estabelece com os processos enigmáticos pertencentes a toda a inspiração poética, que Levi perfila ao longo da sua vida, revelam a pertinência de uma meditação sobre o destino da palavra como instrumento indagador indispensável a fazer parte de uma cultura, por ele encarada de forma unida nas suas vertentes humanística e técnico-científica. No laboratório da palavra que Levi nos legou, quais serão os "elementos" de sentido que se nos manifestam? Em que enigmática Tabela Periódica se inscreverão? Qual, enfim, a sua mensagem radical?
E M 1949, O FILOSOFO ALEMÃO THEODORE Adorno, ao escrever sobre a cultura ocidental que viu nascer o nacional-socialismo, Auschwitz e a Shoah, formula a bem-conhecida proibiçăo da escrita de poesia após Auschwitz, julgando o impulso poético como sendo, desde já, uma voz impossivel, um interveniente eclipsado pela ferocidade destrutiva da realidade histórica de 1933-45, realidade essa que fragmentou os alicerces de uma milenar cultura da palavra considerada até então como vector das energias criativas do ocidente, e de que a poesia era a incarnação privilegiada. Como, interroga-se, se poderá pensar o inumano, i.e., a destruição do carácter dialógi$\mathrm{co}$, civilisador e humanizante da palavra, o inumano que se instalou e perverteu a palavra em si? Qual poderá ser o papel da palavra na difícil tarefa de reconstruir uma reflexão adequada sobre uma nova condição humana, de certo reduzida, emergindo dos escombros do pós-guerra? De algum modo, a palavra, i.e., a linguagem humana como instrumento civilizador eminentemente pedagógico, tornara-se infectal ${ }^{1}$ : tinha testemunhado atrocidades, absorvido ideologias e até tolerado - passivamente ou pior - a criação do universo concentracionário. Como foi possível uma tal degradação da palavra - considerada desde a antiga tradição filosófica grega (uma tradição crítica que se intensificou com o advento da modernidade protagonizada por figuras tais como Bacon, Galileo e Descartes, a emergência de metodologias científicas experimentais, o programa cultural do Iluminismo, etc) como um instrumento de racionalidade e de esclarecimento do ser humano e do seu destino? A partir de agora, como poderá falar e pensar o ser humano? Com que visão, com quais fragmentos de certeza acerca do humano? Como se poderá situar agora este ser, quer no seu contexto histórico, quer cósmico? Como se deformou esta linguagem, a lógica interna de uma cultura ocidental, o seu logos civilizacional de tal modo que pôde alojar no seu interior a irrupção do mal (e a consequente ruptura radical em relação ao saber) que representa a destruição sistemática de milhões de europeus? Adorno declara:

Mesmo a consciência mais radical do desastre corre o risco de degenerar em mera tagarelice. A crítica da cultura vêse confrontada de forma extrema com a dialéctica entre a cultura e a barbárie: escrever um poema após Auschwitz é bárbaro, e este facto afecta o conhecimento em geral e explica a razão por que se tornou impossivel escrever poemas hoje em dia. ${ }^{3}$

Auschwitz representa mais do que um lugar: é uma nova topografia do mundo humano. Mais ainda do que uma nova topografia do mundo humano, Auschwitz deixa transparecer, na sua sistematização do terror, uma fronteira do ser humano radicalmente resistente à mediação racional, uma fronteira do hu- 


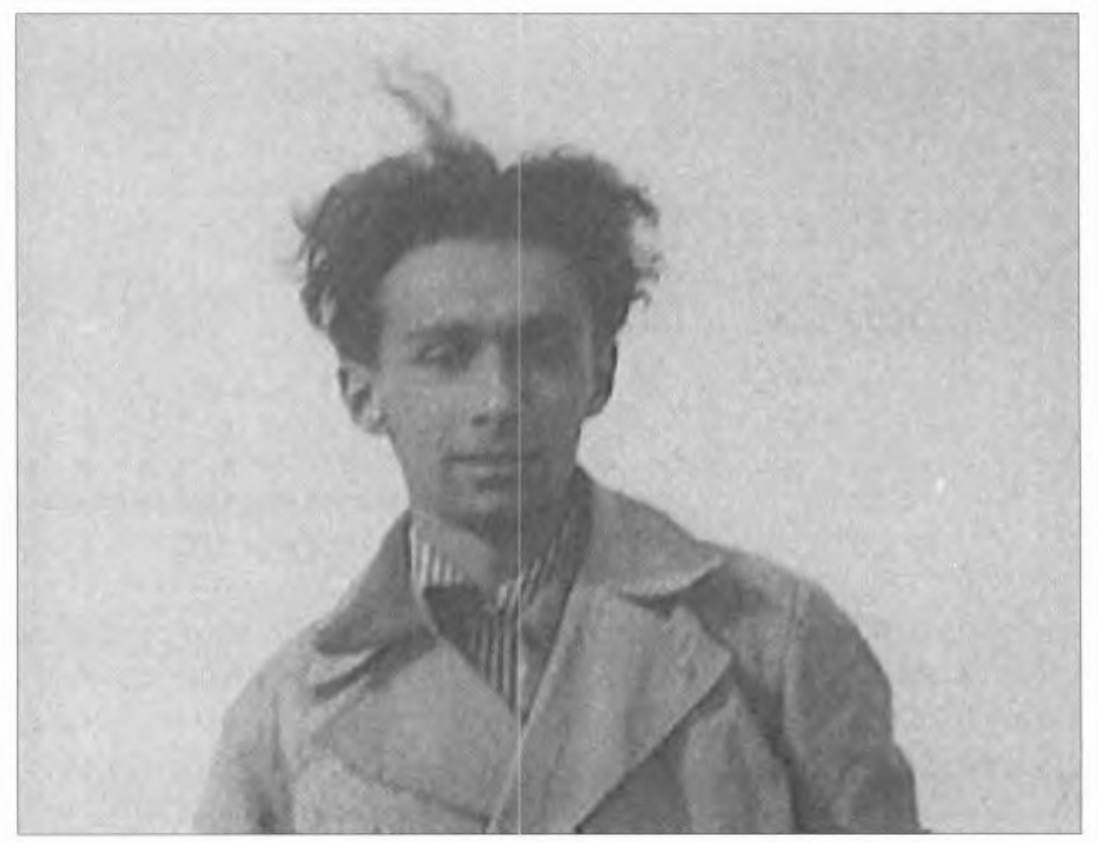

mano paradoxalmente adverso ao humano. Entenda-se portanto que o universo concentracionário de que escreve Adorno exige não só um estudo das raízes históricas que subjazem à formação da mentalidade nazi, mas, mais terrivelmente (e que ele pressente imperiosamente como a necessidade dum silêncio que actua como o requiem dos poderes tradicionalmente atribuídos à literatura) obriga-nos a perder velhas fluências mentais, hábitos conceptuais estabelecidos e pressuposições filosóficas assentes. Auschwitz questiona e problematiza na ira muda das suas cinzas a nossa sempre intuída, mas ao mesmo tempo sempre historicamente condicionada, relação com o mundo. Qual é, porém, a verdadeira natureza desta relação nesta nova situação histórica em que se encontra a humanidade? Auschwitz cria - no questionamento profundo que gera - uma crua incomensurabilidade. (Poder-se-ia escrever, que Auschwitz representa uma ruptura paradigmática.) A partir de agora - seguindo o pensamento de Adorno - será apenas mediante uma reflexão da cultura humana em relação a este mal absoluto que se poderá pensar legitimamente. Não efectuar este trabalho de reflexão equivale portanto a desistir de ser, por assim dizer, um ser humano pois, actualmente, o acto de recordar que é uma das tarefas essenciais duma cultura humana que se actualiza e se identifica mediante a compreensão das energias criativas que a instaurou deve meditar em cada momento das suas reflexões não apenas a possibilidade do esquecimento (a natureza lacunar de toda a realidade histórica cuja interpretação é sempre efectuada, lembre- se, por um ser finito e portanto não omnisciente) mas, mais amplamente, a realização histórica do aniquilamento do recordar em si. Assim, irrompeu a incomensurabilidade; daí adveio a degeneração comunicativa. Decorrem facilmente de una tal situação a instabilidade e até o apagamento da capacidade de uma formação cultural poder funcionar como filtro do irracional, de poder retardar o advento do prolixo e do irreflectido, de poder mediar a precipitada identificação do cidadão com o ideológico e, em última instância, de impedir, mediante uma reactualização das energias civilizadoras do ocidente, a implantação e a contaminação dum mundo totalitário. Resta-nos apontar ainda para o confronto, implícito no texto de Adorno supracitado (e afinal de contas em grande parte irresolúvel), entre a palavra como instrumento humanizante (porque portadora de uma memória, de uma tradição e de uma esperança) e o silèncio ensurdecedor que se apoderou já de todo o acto comunicativo, silêncio este que chegou mesmo a eclipsar, na perspectiva de Adorno, uma das manifestações mais radicais da palavra, i.e., a poesia.

De tal forma esta palavra se deformou que o cientista/escritor Primo Levi (1919-1987) fará da sua obra uma reflexão implícita e até certo ponto uma complexa e por vezes ambigua superação deste novo estatuto degradado da palavra, da palavra antigamente entendida como portadora e propulsora do nosso saber do mundo mas agora convertido em instrumento nocivo, fragmento escuro, horizonte fechado. E este repensar da palavra, esta vivência da palavra que Levi vai registar de forma complexa em relação à sua poesia uma poesia que se manifesta nele como súbita mutação desfigurante do seu corpo - parece reflectir agudamente a situação de crise que o mundo ocidental vive no cerne do seu projecto de modernidade. François Lyotard, ao escrever noutro registo filosófico mas com a seriedade de um fino crítico cultural afim à de Adorno e Levi, no seu ensaio "Reescrever a Modernidade", texto incluído numa colectânea de reflexões da sua autoria e que leva por título $O$ Inumano Considerações sobre o Tempo, afirma que a nossa modernidade se caracteriza desde há já bastante tempo pela "reescrita de alguns traços reivindicados pela modernidade, e antes de mais da sua pretensão em fundar a sua 
legitimidade no projecto de emancipação de toda a humanidade com a ciência e a técnica. Mas esta reescrita, já o disse, está desde há muito em curso na própria modernidade." ${ }^{4}$ Eis portanto uma tensão intrigante que se nos depara na junção das reflexões destes três autores: como se deve encarar - e conciliar - a palavra na sua condição-limite, i.e, na sua manifestação poética, situada esta palavra entre estes dois pólos, o do silêncio absoluto e inultrapassável e o da reescrita geradora de novos textos e mensagens num projecto global de emancipação da história em si? Por um lado, defrontamo-nos com a proibição da poesia (reflexo da erosão radical de que sofre a palavra modernamente) e, por outro lado, activa-se uma "reescrita" cultural intensa, proliferante e ininterrupta (e, recorde-se, no caso da poesia de Levi, de forma incompreensivel e incontrolada), i.e., o questionamento intenso da nossa cultura mediante essa mesma palavra em que a poesia surgirá como mais um elemento de mediação e meditação dum mundo crescentemente tecnológico. A poesia não representará afinal um vector de comunicação, revelação e indagação de novo inprescindivel para este projecto de reescrita contínua do mundo? Certamente a presença de poesia na obra de Levi - e a meditação complexa e até ambígua deste em relação ao significado real da sua poesia - sugere a vitalidade e a permanência destas questões.
E neppure Primo Levi escreve poesia. Ex-deportado de Auschwitz (häftlinge, i.e., prisioneiro registado e "baptizado" com o seu novo "nome": 174 517, número tatuado no seu antebraço esquerdo), químico (chegando mais tarde, após a sua libertação pelos aliados, a ser director de uma indústria química de tintas localizada nos arredores de Turim, i.e, a SIVA (Società Industriale Vernici e Affini), e escritor que se dedicou à criação duma obra de testemunho (vejam-se as suas duas primeiras publicações Se questo è un uomo, 1947 [Se Isto É Um Homem, Teorema, 1988] e La tregua, 1963 [A Treva], ficcionista (contos filosóficos, romances, e ficção cientifica), comentador cultural (publicando as suas crónicas regularmente durante quarenta anos em La Stampa, o grande diário de Turim - a sua cidade natal - e tradutor, 5 Primo Levi publica igualmente poesia sua por duas vezes, a primeira vez em 1975 numa colectânea de vinte e sete poemas intitulada L'osteria di Brema, sendo estes poemas reeditados e incluídos nove anos mais tarde numa colectânea intitulada Ad Ora Incerta, apresentando, para além desses previamente publicados, mais trinta e quatro poemas. Não sem constatar as condições especiais, quase adversas mesmo, sob as quais aparece o texto poético. Em carta a um leitor da sua primeira colectânea de poemas, Levi responde:
Escrevi o meu primeiro poema após o período passado em Balengero, em 1943, perto de Turim. Escrevi mais uma quinzena em 1946, após a publicação do meu primeiro livro, quando trabalhava na Duco, em Avigliano. Os outros poemas escrevi-os entre 1949 e 1974. Porquê? Ora, escrever poesia pertence a um processo mental que desconheço em grande parte e que controlo muito pouco. A minha faceta racional reprime tudo o resto. Os poemas são o resultado de uma emotividade que dificilmente consigo analisar. Enquanto escritor, tenho-me esforçado por ser claro. Ignoramos tudo aquilo que existe por trás da nossa racionalidade. As nossas profundezas são-nos desconhecidas. Pode ser que a poesia seja o resultado de duas mãos esquerdas. 6

Esta imagem insólita de "duas mãos esquerdas" é duma grande riqueza simbólica, sugestiva de uma fluência interrompida e de uma escrita quasi-impedida, sobreviva a um handicap insólito, i.e. a súbita ausência de simetria manual. Esta descodificação da mão, por assim dizer, reflecte cabalmente a situação-limite em que se encontra o escritor ao produzir poesia. Na verdade, o poeta sabe, e o seu corpo regista, a situação in extremis da sua linguagem ao produzir um poema. A escrita - sob tais condições adversas - constitui um acto comunicativo ao mesmo tempo tolhido e, por isso mesmo, excepcional. A poesia

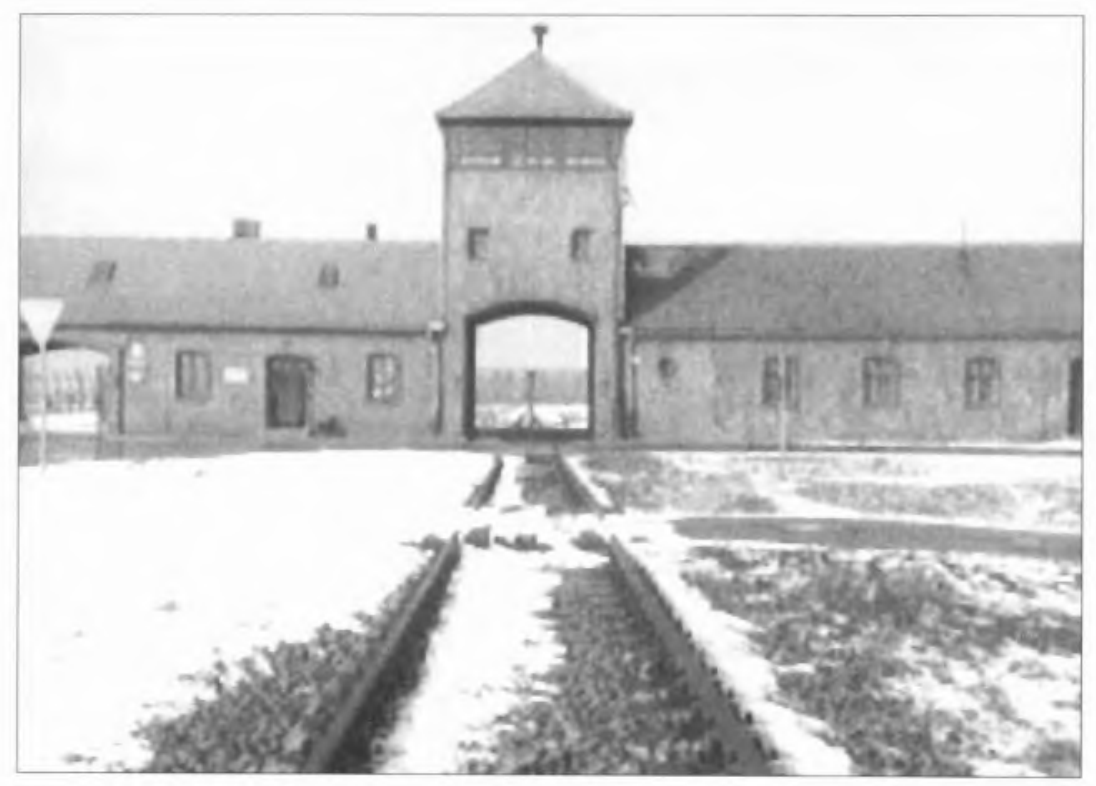




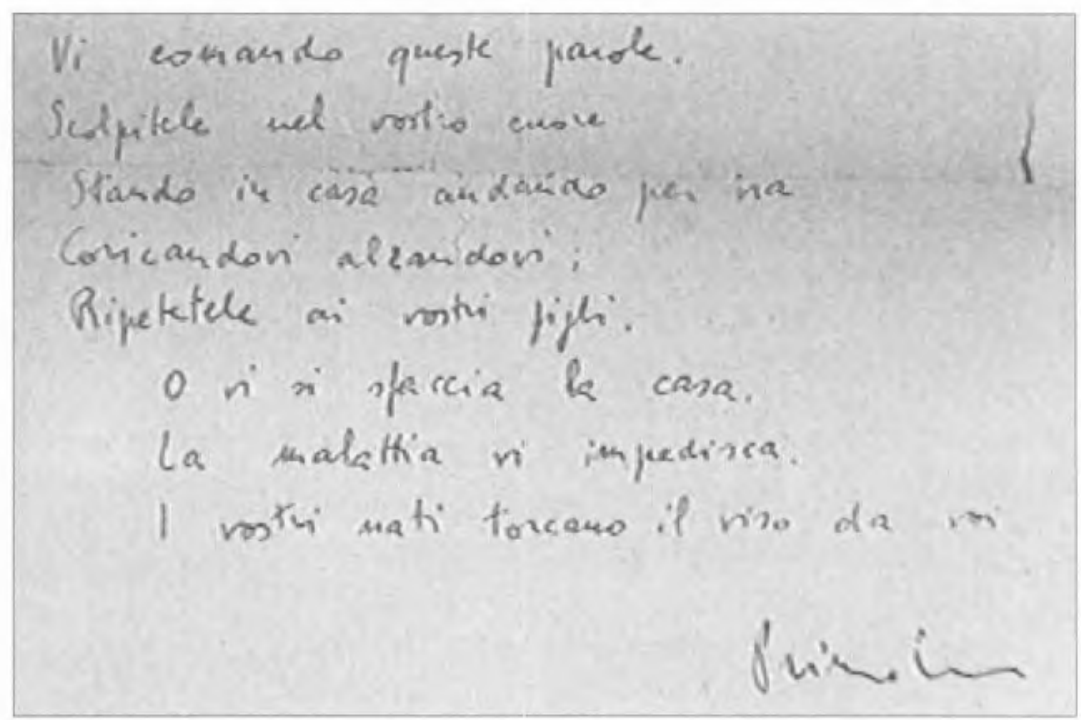

surge, ou melhor, irrompe contrariamente aos hábitos mentais deste escritor criador, como é sabido, de uma prosa quase laboratorialmente destilada, filtrada, e medida; uma prosa que procura criar um espaço claro, pausado, e deliberativo de modo a poder, prioritariamente, examinar e compreender um povo e a sua ideologia. Em contrapartida, a sua poesia, constata ele em várias ocasiões, encarna um momento de dramática descontinuidade, de ruptura na vida do escritor que ele não consegue decifrar as condições essenciais da génese da sua poesia. Escreve poesia como se se tratasse de subitamente se encontrar na finisterrae da própria racionalidade. Levi vive a sua poesia como se se tratasse de uma incomensurabilidade interna. A sua incapacidade de explicar o processo poético que contudo produz ao longo da sua carreira de escritor permite-nos uma primeira abordagem à difícil questão da expressão poético no mundo pós-Auschwitz. À incomensurabilidade histórica apontada por Adorno, Levi, contrariando a proibição da escrita de poesia (tornada obsoleta, segundo aquele, pelas novas coordenadas da nossa condição humana), vive a poesia como necessidade imperiosa, embora experiência incompreendida e incontornável. Ao corporizar os efeitos disformes, inexplicáveis do fenómeno poético, Levi atinge, criativamente, num acto comunicativo de compromisso total (porque é o destino do corpo que está em jogo em conjunto com o destino da própria linguagem com que o escritor o exprime) um estado anterior à consciência e anterior à actividade racionalizante, i.e., anterior igualmente à palavra como instrumento de domínio e de massificação do ser. Paradoxalmente, se para Adorno, Auschwitz representa o fim da poesia, para Levi reflecte exactamente a condição in extremis em que se debate 0 destino da palavra no ocidente. Assim, segundo as suas próprias afirmações, a poesia não deixa de ser vector de contacto humano. Ao mesmo tempo que o evento poético ameaça suprimir as fronteiras racionais do químico/escritor, torna possivel, por isso mesmo, uma comunicação mais radical da experiència do mal e, reparese, da modernidade após Auschwitz. Por constituir uma experiência do incomensurável, por incarnar uma condição-limite da linguagem humana, a poesia consegue captar algo de mais obscuro, mais primordial e mais próximo do incomunicável - e, por isso mesmo, garante a continuação da comunicabilidade. Ironicamente, pode ser que após Auschwitz só nos reste a poesia como autêntica expressão do seu significado radicalmente desagregador, desmembrante, destruidora de simetrias pacificas. A poesia irrompe no instante de a palavra como instrumento de deliberação e de racionalidade fugir às arrecuas face àquilo que não pode senão ameaçar ou negar o próprio raciocínio. Só assim, nos confins do nomeável é que surge esse súbito aguçar da consciência, i.e., esse suspender momentâneo da razão habitual que não deixa de ser o estado precursor de uma compreensão nova do mundo.

Afinal de contas, a poesia é indispensável após Auschwitz precisamente porque é dotada da capacidade de alcançar um grau de anterioridade fundadora de uma reflexão nova - afim ao evento histórico de Auschwitz em si. A poesia, ao modo do universo concentracionário, representa dois horizontes negativos; se, por um lado, Auschwitz é um horizonte absoluto do mal, a poesia, por seu lado, é o horizonte negativo e absoluto do corpo, da consciência e do mundo: o momento negativo da sua descodificação, como vimos numa abordagem à imagem significativa das "duas mãos esquerdas" de que fala Levi. A gaguez corporal destas duas mãos constitui a via emancipativa ulterior da palavra e não a sua paralisia. A transcendência que nos resta hoje em dia reside proventura na possibilidade de meditarmos sobre o estado negativo da palavra, i.e., o comunicar a partir do silêncio e o inumano. Levi não limita as maneiras de narrar esta (in)transcendência, mas, antes, pratica-as e multiplica-as a um nivel de profundidade e de entrecruzamento insólitos. Só assim é que essa anterioridade permitirá emergir o novo, a palavra renovada, os horizontes ainda possíveis, i.e., a descoberta de novas narrativas e de novas maneiras de as contar numa modernidade que se reescreve continuamente. 
Esta reescrita não deverá porém deixar de encerrar na sua lógica interna a memória do mal que o fundamenta e que de algum modo ela própria produziu. 0 novo - gerado por este projecto de reescrita - existe de facto só porque pertence a um fundo renovável e específico de questionamento. 0 novo, entendido assim, seria a manifestação do intervalo de pasmo que marca a relação entre o ser e o compreender.

Em última instância, o novo funda-se num salto imaginativo refractário à leitura literal do mundo (que na verdade não existe) - numa memória experiencial que subjaz a todo o projecto de significação, i.e., na intuição de que o mundo se relaciona connosco de modo essencial. Precede portanto a nossa consciência indagadora uma fé implícita na doação duma resposta às nossas dúvidas, dum responder, embora sempre parcial, do real às nossas indagações, sendo estas fruto do relacionamento duradouro do ser humano com o espanto de haver mundo e de nele se encontrar. O poema "Agave" de Primo Levi parecenos exemplificar precisamente o drama de um ser que só se completa na angustiosa aceitação da sua finitude; só pode comunicar a sua natureza incompreendida no momento da sua existência ser agonia de florescimento e de extinção; só se culmina no instante do seu destino se revelar como simultanea- mente possibilidade e opressão; só transcende a sua contingência ao assumir-se como projecção irracional mas necessária para dentro do mundo, um mundo que será congeminado com, simultaneamente, a razão de ser do "agave" e a testemunha da sua indecifrável persistência. 0 poema constitui, portanto, uma imagem da vocação poética em si, tal como se evidencia na obra de Levi, lá onde a memória do inumano se aguça eruptivamente como dolorosa possibilidade e o humano como fruição comunicativa urgente e, contudo, periclitante:

Não sou nem útil nem belo,

Não tenho nem cores alegres nem

[aroma;

As minhas raizes roem o cimento,

$E$ as minhas folhas, orladas de espi-

Inhos,

Ao modo da ponta duma espada, protelgem-me.

Sou mudo, tenho apenas a minha lin-

Iguagem de planta,

Para ti dificil de compreender, homem.

Uma linguagem obsoleta,

Exótica, pois venho de longe,

Dum país cruel,

Cheio de vento, de vulcões e de veneInos.

Tenho aguardado longos anos antes de [exprimir

Esta minha flor imponente e desespera[da,
Feia, lenhosa, rígida, mas erguendo-se

lao céu.

É a minha maneira de gritar que

Amanhã morrerei. Compreendes-me

[agora? 7

Assim, o autor escreve poesia como se fosse uma fatalidade que o transcende; o poema representa um evento de significação eruptiva, irredutível e ferozmente presente. Este estado de urgência comunicativa, e a concomitante constatação das condições adversas nas quais se realiza, é um tema frequentemente abordado por Levi e os seus interlocutores e leitores. Levi, numa entrevista publicada no Corriere della Sera em 28 Outubro 1984, responde à sua entrevistadora - no preciso momento em que esta lhe lembra a proibição da escrita de poesia após Auschwitz, por parte de Adorno - da seguinte maneira:

\section{A minha experiência prova o contrário.} Na verdade, nessa altura, parecia-me que a poesia estaria mais apta do que a prosa para exprimir tudo que me oprimia. Quando falo de poesia, não estou a pensar em nada de lírico. Naquela época, teria reformulado a frase de Adorno assim: após Auschwitz, só se pode escrever poesia sobre Auschwitz. ${ }^{8}$

Esta afirmação de 1984 é posterior à previamente citada referente às "duas mãos esquerdas" (datada de 1975), e

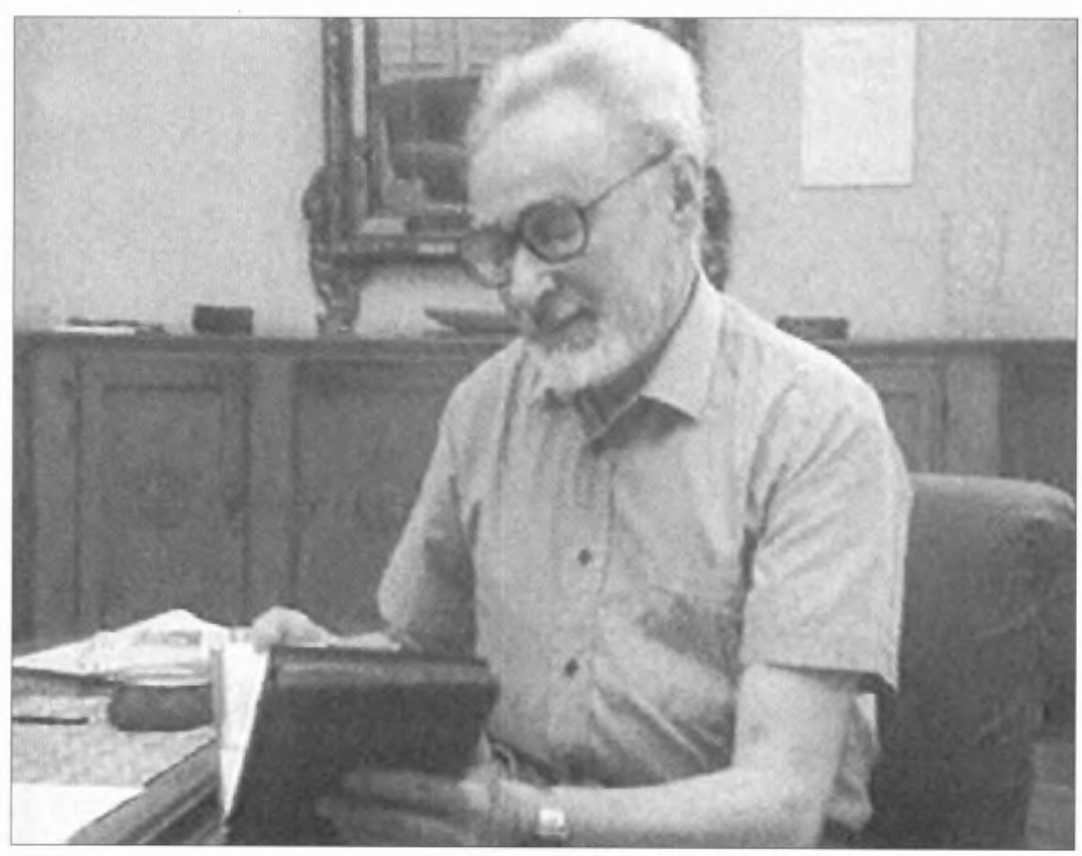


representa uma reelaboração racionalizante face a outras numerosas afirmações suas que frisam o carácter descontínuo do evento poético na sua vida e obra. De facto, nesta perspectiva agora expressa, Levi considera a realidade de Auschwitz como um evento tematicamente agregador em relação à escrita poética, levando a vislumbrar a possibilidade de tornar este evento susceptivel de uma reflexão sobre as suas causas e significado ulterior. Ora, a história da sua escrita em prosa "sobre Auschwitz" revela este tom de deliberação cautelosa. Uma leitura da sua obra em prosa permite-nos apreciar os múltiplos caminhos seguidos por Levi para tratar questões afins em moldes e universos narrativos divergentes, uma linguagem, contrariamente à sua poesia, que privilegia o contínuo sobre o caótico e o alegórico sobre o eruptivo. Em 1975. por exemplo, Levi, depois de escrever dois livros sobre a sua experiência no Lager, publica uma escrita menos cingida à linguagem do depoimento e da testemunha. Na autobiografia espiritual do químico/escritor que é o seu Sistema Periódico, o escritor tece uma narrativa que revela a sua capacidade de combinar uma atenção meticulosa ao mundo (reflectindo fielmente o combate livrado pelo químico à matéria, à natureza, um combate que é organizado neste livro de acordo com uma forma enraizadamente sistemática, i.e. ao modo da tabela de elementos químicos esboçada pelo russo de São Petersburgo, Dimitri Mendeleiev) com uma fina estrutura alegórica que ele estende sobre a tabela periódica rememorada agora como expressão de uma realidade físico-química inviolável e horizonte máximo da sua aprendizagem humana - um acto de rememorar, recorde-se, que deve confrontar e superar precisamente esse estado de ruptura, esse estado-limite da linguagem humana que desafia 0 acto de rememorar em si de que escreve Adorno. De facto, como recordar quando serve apenas para rematerializar o aniquilamento? Como procurar na escrita poética, repita-se, uma catarse, uma lição, uma analogia sequer com a experiência dos Lager? Como dar crédito a uma memória literária, a uma tradiçāo milenar que definiu e delimitou o território do poético fcra do Lager? Como podemos reencontrar-nos na palavra bestializada? ${ }^{9}$ É este dilema, repita-se, que qualquer escrito deve interiorizar e que Levi explora até às suas últimas consequências. Olhando de novo para o seu Sistema Periódico, podemos apreciar o mundo de Levi, o narrador, face a Levi, o poeta. Leia-se, por exemplo, o último capítulo desta obra, que tem por título e tema o carbono; não o carbono em geral, mas a imaginada trajectória milenar dum só átorno de carbono que Levi traça ficcionalmente. O leitor nâo demora a aperceber-se de que a trajectória descrita deste átomo adquire na narrativa o estatuto de uma viagem iniciática de clara ressonáncia universal. Levi comunica ao leitor com evidente deleite os processos químicos invisíveis desta sua personagem ao nesmo tempo que descortina a continuidade possivel (que a consciência humana torna iminente) entre o mundo do cientista e o mundo da consciência humana, entre a história natural do mundo que nos precede e que perdurará muito para além da nossa passagem mortal e a memória do mundo que cada individuo actualiza, ora entregando-se a uma passionalidade destrutiva, cra laborando a fim de construir uma memória cultural que transcenda a promoção de, ou a complacência no, caos. 0 mundo é a concretização - por via da escrita - de uma compreensão renovadamente possivel; os horizontes deste mundo existem precisamente porque se pressentem como uma realidade por fazer. Eis por um lado, as energias centripetas do sistema, do sistemático, $10 \mathrm{e}$, por outro lado, as energias centrifugas, dispersivas do ser humano. Contudo, Levi sabe que a pedagogia dum optimista (que ele confessadamente é) depende da sua capacidade de articular um mundo - o seu ritmo de enigmas e descobertas - numa linguagem que registe a tensão entre o sistemático e o dispersivo, i.e. entre a palavra como instrumento de comunicação e o silêncio. ${ }^{11}$ Só assim é que a escrita poderá transcender a dispersão. Contudo, transcender não significa sarar de vez. Veja-se por exemplo o poema "Aracne", datado de 1981, e ra- pidamente se apercebe do facto de haver substratos significativos da personalidade criativa de Levi que se abrem continuamente à experiência de ruptura, onde a palavra não se deixa pautar pelos ritmos mais serenos da sua prosa, mas antes se the impõe como cenáric incontornável. 0 poema comunica um ambiente perturbante onde a memória curta da "aracne" cumpre com as suas tarefas infinitamente repetidas (reflexo puro de uma lógica inquestionada e portanto inumana). O fascínio horrorizado do poeta leva-o a precipitar-se para dentro da mesma teia que a "teia" de palavras poeticamente constitui:

Sentar-me-ei no centro da teia

Até se aproximar o macho,

Cauteloso mas, sobretudo, audaz com o Idesejo,

De encher meu estômago e meu ventre Ide um só golpe.

Assim que anoitecer, ágil, feroz,

Tecerei uma teia nova,

Nó após nó, rápido, sobretudo rápido.12

Aqui não há autobiografias possíveis; aqui impera uma lei selvagem e implacável, refractário à razão, quer à luz deliberativa da prosa, quer às epifanias da poesia. 0 poema devora o sossego do observador; devolve-o à noite da consciência.

Levi não perde a consciência do seu valor e de uma maestria que aperfeiçoou ao longo de quarenta anos de escrita. Não se fechou ao evento da palavra, mas antes assumiu plenamente a sua convivência complexa e por vezes árdua com ela. Em vez de silenciar a poesia, deixou que ela o exprimisse numa linguagem radiante e dolorosa, apostando assim na possibilidade de fazer da memória do mal a raíz duma comunicaçāo mais profunda sobre o que o ser humano, face às suas responsabilidades, compromissos e experiências, ainda pode e deve esforçar-se por entender, embora tal comunicação o leve aos confins do corpo e do mundo:

Na verdade acredito que o meu destino intimo ... é o hibridismo, a cisão. Italiano, sou contudo judeu. Químico, sou também escritor. Embora seja um antigo deportado, raramente (ou quase nunca) 
estou disposto a me lamentar ou a tornar-me polémico... Por vezes, face à página branca, encontro-me num estado de espirito que classifico de férias sabáticas. Então, nessas alturas, apraz-me escrever extravagâncias e imagino que aos meus leitores Ihes apraz igualmente lê-las. É certo que alguns críticos, e não poucos leitores, preferem os meus livros sérios; esse direito pertence-Ihes, mas eu tenho igualmente direito às minhas fugas. Isto por, pelo menos, uma boa razão: para me auto-indemnizar, e, igualmente, por que, em geral, amo a vida. ${ }^{13}$

Só assim, afinal, é que a palavra se torna humana, não apesar da dimensão inumana da sua história mas precisamente devido à capacidade de um ser poder tornar-se testemunha do mal de que esta palavra é portadora e memória viva, e, contudo, amar a vida.

Primo Levi nasce em Turim em 1919. Licencia-se em Quimica, na Itália de Mussolini numa época em que já vigoram as leis raciais contra os judeus. Participa na resistência contra a ocupação nazi, é preso e internado, primeiro num campo italiano, e, pouco tempo depois, no campo de concentração de Auschwitz. Libertado em 1945, o autor exerce funções de químico nos quarenta anos seguintes, chegando a ser director de uma indústria química de tintas nas proximidades da sua cidade natal. Concomitantemente, Levi criará uma obra de testemunha e depoimento das suas experiências em Auschwitz, bem como fará múltiplas incursōes (algumas galardoadas com prémios) em vários géneros literários: romance, contos, contos de ficção cientifica e, também, poesia. É colaborador assíduo do grande diário de Turim, La Stam$p a$, onde publica centenas de artigos de reflexão ensaistica, fábulas e comentários culturais, até poucos dias antes do seu suicídio em 1987.

\section{Notas}

1 É Primo Levi que nos sugere o adjectivo. Numa entrevista datada de 1981, ele referese à sua poesia da seguinte maneira: "Por natureza, eu não faço poesia, contudo, de vez em quando, apodera-se de mim uma curiosa infecção, como se se tratasse duma doença exantemática, que produz uma espécie de urticária. (...) É um fenómeno que não compreendo, que desconheço, que não sei teorizar, portanto algo de que recuso o próprio mecanismo. Não faz parte do meu mundo. No meu mundo, pensa-se numa coisa, e, a seguir, desenvolve-se quase como... um motor, é isso, constrói-se pouco a pouco. Aquele outro mundo, onde tudo é produzido de modo fulgurante, deixa-me num estado de perplexidade" in Primo Levi, Conversations et entretiens, (Paris: Roberto Laffont, 1997), 183. (itálico nosso). 0 que nos parece digno de reflexầo reside precisamente na valorização complexa da palavra poética que se esboça ao confrontarmos a proibição de Adorno relativamente à escrita de poesia com a prática poética de Primo Levi que admite a infecção sem jamais chegar a uma compreensão clara da sua natureza e da sua génese. Provisoriamente, podemos aventar o seguinte: onde Adorno, por um lado, suprime a poesia, Levi deixa-se parcialmente suprimir pela sua irrupção fulgurante. Face ao mesmo fenómeno de escrita, Levi vive o evento da poesia como se ele estivesse a testemunhar algo que, embora partindo dele, não lhe pertencesse nem fosse parte integrante dos seus hábitos de quimico e escritor profissionais. Face ao evento de Auschwitz, Levi e Adorno reconhecem uma ruptura. Os dois aceitam o mundo dos Lager como divisório absoluto entre um antes e um depois. Se Adorno rejeita a poesia como um desvio nocivo, uma distracçăo de expressāo tornada obsoleta, uma atitude tornada supérflua, Levi aceita-a malgré lui. Há um evento anterior a tudo; uma crise de pensamento e de acção anterior a toda a consciência humana, e que se chama Auschwitz. Levi, contudo, e caracteristicamente, verá na poesia, apesar de representar para ele um evento sem paráfrase racional, uma maneira de criar um diálogo intimo entre as pessoas, i.e., descobre nela um valor humanizante, um impulso pedagógico, uma forma lúcida, portanto, de não compreender, um questionamento radical da palavra em si: "Tenho a impressão de que a poesia, no seu todo, se tornou actualmente num prodigioso instrumento de contacto humano." ibid, 139.

2 Para uma reflexão sobre a teologia após Auschwitz, veja-se Hans Jonas, "The Concept of God After Auschwitz: A Jewish Voice*, in Mortality and Morality A Search for the Good after Auschwitz, (Evanston: Northwestern University Press, 1996), 131-43.

3 Critique de la culture et de la société. Escrito em 1949, é publicado em 1951, in So- ziologische Porschung in unsere Zeit. Tradução francesa in Prismes, Payot, 1986.

4 François Lyotard, O Inumano Consideraçōes sobre o Tempo, (Lisboa: Editorial Estampa, 1997), 42.

5 Ser-the-á encomendada uma nova tradução d'O Processo de Kafka pelas editora italiana Einaudi - uma obra cuja visão dum mundo regido por leis implacáveis emanando misteriosamente duma burocracia tirânica perpassada por uma inominável opressividade - atrai e horroriza um Levi apreciador dos poderes proféticos do escritor de Praga, falecido uns vinte anos antes do funcionamento dos fornos crematórios de Birkenau, mas cuja obra difere radicalmente da do seu tradutor turinense.

6 Citado in Myriam Anissimov, Primo Levi ou la tragédie d'un optimiste (Paris: JC Lattès, 1996), 492.

"As duas mãos esquerdas" já se encontram devidamente rectificadas, tendo sido recuperada a sua simetria anatómica, na equanimidade do escritor ao escrever // Sistema Periodico, 1975 [O Sistema Periodico, Gradiva, 1988]. Lembre-se que nesta obra em prosa Levi fez da tabela periódica dos elementos químicos a imagem central da sua identidade humana multifacética, i.e., o livro sintetiza e concilia as suas vertentes de testemunha e sobrevivente da Europa fascista, de químico profissional e de escritor. Levi rejeitou desde os seus dias de liceu a espúria divisâo da cultura em humanistica e científica. Num texto publicado em La Stampa em 1979, Levi afirma o seguinte:

"É um lugar comum recusar uma das duas culturas como sendo reciprocamente exclusivas. Para Galileo, não havia duas e também não havia duas para Einstein. Esta recusa, quer-me parecer, representa a deformação típica feita na Europa de erguer uma barreira entre a cultura humanistica e e cultura científica e técnica." citado in Arissimo, 505 .

7 ['Non sono utile né bella,/Non ho colori lieti né profumi;/Le mie radici rodono il cemento,/E le mie foglie, marginate de spine,/Mi fanno guardia, acute como spade./Sono muta. Parlo solo il mio linguaggio de pianta,/Difficile a capire per te uomo./E un linguaggio desueto,/Esotico, poichè vengo de lontano,/Da un paese crudele/Pieno di vento, veleni e vulcani./Ho aspettato molti anmi prima de esprimere/Questo mio fiore altissimo e disperato,/Brutto, legnoso, rigido, mas teso al cielo./E il nostro modo di gridare che/Morrò domani. Mi hai capito adesso?"] Primo Levi, Ad Ora Incerta, (Gar- 
zanti: Gli Elefanti Poesia, 1990), 71. (tradução portuguesa nossa)

8 Primo Levi, Conversations et entretiens, (Paris: Robert Laffont, 1998), 140.

9 Paul Ricœur explora estas questões numa entrevista inicialmente publicado em 1975 e cuja traduçẫo portuguesa tem por título, "Política e Totalitarismo". Relativamente à condição radicalmente adversa da palavra que vive o escritor, a análise feita pelo filósofo francês acerca do Estado totalitário e as suas consequências desumanizantes é sumamente pertinente: "Qual a sua tendência natural? $\hat{E}$, antes de mais, a de totalizar as relações humanas, dissolvendo todos os outros laços sociais; ê produzir uma humanidade-massa tal que já não obedeça a nenhum outro princípio organizador a não ser o Estado, encarnado na pessoa do chefe. Não foi, portanto, por acaso que o totalitarismo produziu a exterminação, ou seja a morte infligida em massa: pela destruição dos laços inter-humanos, a humanidade torna-se uma massa perdita, onde os moribundos e os mortos são quase indiscerniveis. (...) Não será af que importa ver a essência do totalitarismo, na exterminação institucional tornada possivel pela eliminação de tudo o que fazia organicamente o tecido social? Os mortos em massa são o sinal ou o indício do carácter exterminador próprio do regime totalitário; atestam o facto de que a morte não é ai um acidente, mas contaminação, gradualmente, dos que já estão mortos em direcção aos moribundos; existe, no principio do totalitarismo, uma experiência proliferante da morte". Paul Ricœur, A Critica e a Convicção, (Lisboa: Edições 70, 1997), 15152. (itálico nosso)

10 Recordem-se a gumas das definiçōes da palavra sistema dadas pelo Dicionário Etimológico da Lingua Portuguesa, Livros Horizonte, 6a edição, 1990: "reunião num só corpo de diversos objectos, de partes diversas do mesmo objecto; conjunto, total, massa; grupo, grupo de pessoas, multidảo".

11 Vejam-se as afirmações extremamente pertinentes feitas por Ricœur a propósito desta experiência do dispersivo e o seu relacionamento com uma definição do mal. 0 contexto histórico das suas afirmaçōes que a seguir transcrevemos é precisamente o do mundo totalitário e da sua natureza política e humana: "(...) [Q]uando chegamos à exterminação em massa, estamos efectivamente perante o dissemelhante em estado puro, do mal como essencial dissimilitude. E impossivel comparar as formas do mal, totalizá-las, precisamente porque o mal é por natureza dissemelhante, diabólico, ou seja dispersão, divisão. Não há sistema do mal; o mal é sempre o unicamente ünico". Ricœur. ibid, 154. (itálico nosso)

12 ["Mi siederò nel centro/E aspetterò che un maschio venga,/Sospettoso ma ubriaco de voglia,/A riempirmi ad un tempo/Lo stomaco e la matrice./Feroce ed alacre, appena sia fatto buio,/Presto presto, nodo su nodo,/Mi tesserò un'altra tela". I Primo Levi, Ad Ora Incerta, 60, (traduçāo portuguesa nossa)

13 Levi, Conversations et entretiens, (Paris: Robert Laffont, 1998), 186.

\section{Dois textos de Primo Levi}

\section{0 rival oculto}

Durante muito tempo recusei ter jogos em casa: disto tenho várias testemunhas fidedignas. Tenho, sim, desde há um ano um teleprocessador; agora pertence, quase como um orgão, ao meu corpo, tal como sucede com um par de sapatos, ou óculos, ou dentes postiços; é-me absolutamente indispensável quando escrevo ou organizo os meus apontamentos em fichas; faço tudo, porém, para que tal instrumento não se apodere de mim. Por conseguinte durante muito tempo não quis ter em casa nenhum daqueles frívolos jogos que hoje em dia são tão populares. Dizia eu que o computador servia apenas para trabalhar, nada mais. Contudo, aconteceu o improvisto (ou talvez o previsto) Recebi recentemente um presente: um programa de xadrez - e, claro, já fui seduzido por ele.

Falemos sem rodeios: jogar xadrez não é uma actividade frívola para verdadeiros jogadores, ou, em geral, para aqueles que se dedicam a este jogo com seriedade e paixāo - para mim, porém, não deixa de ser frívolo. $E$, verdade seja, jogo bastante mal: nẫo estou munido das qualidades fundamentais necessárias para este jogo: a capacidade de concentração, o rigor lógico, a memória indispensável e a preparação cultural específica. Mas mesmo assim jogo, e de um jeito frivolo e descuidado. Jogo entre intervalos irregu ares e extensos sem me esforçar por aprender as aberturas e os fechos clássicos. Jogo quando me vejo perante um adversário que joga mais ou menos como eu, com o mesmo espírito festivo e sonolento, e que possui um nível de competência semelhante ao meu: se ele for avançado de mais, fico completamente esmagado aos seus pés, e se for demasiado inexperiente, a minha vitória é inglória e assemelha-se ao acto de roubar um doce a um bébé. O xadrez constitui de facto o único jogo que não rejeito e ao qual continuo fiel: fico abalado quando perco uma partida, mas fico incólume quando ganho. Não aceitei este jogo por razões de ordem dinástica: de algum modo, cuja razão me é obscura, o tajuleiro de xadrez incorporou os nossos "lares"; talvez este tabuleiro seja o único artefacto que se tenha transmitido materialmente de pai para filho. Desconheço, é verdade, quantas gerações dos nossos antepassados têm ensinado aos seus filhos as regras deste jogo, e quantas vezes derrotaram os filhos durante alguns anos até admitirem tacitamente a superioridade dos seus progénitos. Não quero dizer com isto que a qualidade do jogo vá melhorando de geração em geração: penso que o talento para o xadrez atinge 0 auge por volta dos vinte anos de idade e que posteriormente vai declinando à medida que se envelhece - um facto deveras triste mas irrevogável.

Ora bem. 0 jogador electrónico entrou com estrépito neste cenário tradicional. Após termos rendido homenagem à confraternidade de inteligências perspicazes que desenvolveram este programa, resta-nos fazer uma comparação obrigatória: quem é o rival mais desejável? Um homem ou uma máquina? A nossa resposta será necessariamente vaga, porventura evanescente: uma comparação por norma faz-se entre termos intrinsecamente comparáveis, e a nossa pergunta está desprovida de relações afins. Mas vejamos se é possivel analisar a situação de outro modo.

A máquina está sempiternamente à nossa frente, a qualquer momento do dia ou da noite. Não temos de convidála à nossa casa nem temos de nos deslocar a casa dela, pois está sempre ao 
nosso dispor, sem nunca se fatigar nem enervar-se, nem tentar enervar-nos (ao contrário do que fazem os nossos rivais humanos, sobretudo os melhores jogadores têm fama de o fazer). Pode ser programada de acordo com os vários níveis de competência idêntico ao nosso. Esta potencialidade tem porém um preço: quanto mais avançado for o rival, maior é a demora de concretização de um lance no tabuleiro. Ora, uma demora de cinco minutos, quando se trata de um rival humano, é perfeitamente tolerável: fitamo-lo enquanto ele fixa os olhos no tabuleiro; tentamos decifrar no seu rosto os sinais de uma intenção ou, pelo menos, o seu estado emocional. O rival electrónico, contudo, é hermético: ele pondera também durante o tempo que Ihe concedemos, mas, em todo este processo célere de examinar os seus lances possiveis no ecrã, não manifesta mais do que um ilegivel enxamear de sinais, uma sequência de hipóteses em desfile tẫo velozes (cinco ou dez hipóteses por segundo) que não temos oportunidade de o desmascarar. Os cinco minutos de um rival electrónico parecem-nos de facto imensamente prolongados.

Repito: pode-se escolher um antagonista que joga bem, ou que joga de um modo menos competente, ou, até, medíocre: em cada caso jogará com um estilo que não é humano. 0 homem tem rasgos de iluminação (e nem sempre restritos a um tabuleiro de xadrez) em que ele se supera a si próprio e que se podem traduzir neste caso em lances absolutamente inspirados, que, por regra, poderão ser postos em realce por um ou dois pontos de exclamação; este mesmo homem, no entanto, pode igualmente ter momentos de distracção (momentos que poderemos denotar com pontos de interrogaçāo), cuja frequência cresce na fase derradeira de um jogo ou da vida de um jogador. 0 rival electrónico é por outro lado unidimensional: jamais executa um lance que merece a nossa exclamação. Todavia, nunca está desatento e nunca envelhece.

Isto não quer dizer que seja infalível. Erra, e mais: erra sempre da mesma maneira: por exemplo, reparei que o rival electrónico é precipitado e ávido; no caso de haver uma peça numa posição vulnerável, ele ataca como uma ave de rapina, mesmo que, na outra metade do tabuleiro, já se vislumbre a sua própria ruína. Estes erros representam sem dúvida lacunas inerentes à sua programação; uma vez identificadas, é possível explorá-las e sair vitorioso. Mas claro, neste caso, todo o prazer que o jogo nos poderia facultar também desaparece.

Com o jogo electrónico recebe-se todo uma variedade de comandos que são. por assim dizer, puramente acessórios. Por exemplo, pode-se gravar o jogo: se foi muito bom, pode ser gravado e ser passado inúmeras vezes de modo a permitir revivê-lo com emoção. Pode interromper-se o jogo em qualquer momento e continuá-lo mais tarde. Se tivermos dúvidas quanto ao próximo lance, é possível pedir conselhos à máquina que nos responderá de um modo extremamente gentil e cortês. Se, como é o meu caso, se abrir o jogo de um modo relativamente fraco (os jogadores de xadrez realmente competentes sabem estes lances de cor), pode-se comunicar à máquina que cancele os lances fracos que possui no seu reportório de modo a tornar mais equilibrada a nossa deficiência. Após cada lance os resultados aparecem iluminados no ecrã, que logo codifica o estado do jogo com base em parâmetros complicados. Se os resultados forem positivos, obtemos uma indicação muito clara de que não estamos a jogar bem; se se ultrapassar os quinhentos pontos, aconselha-nos a uma retirada airosa; porém, se se ultrapassar os mil pontos, a catástrofe é iminente.

Inversamente, os resultados com um valor negativo, indicam-nos que estamos a ganhar em termos de pontos ou em termos de posiçâo no tabuleiro. É evidente que, se o comentador-dialogante mudo situado à nossa frente nos incomodar, é facilmente eliminável. Podemos até pedir que a máquina jogue contra si própria: o jogo que assim se desenvolve e de que somos testemunhas tem algo de alucinatório, pois nunca se repetirá em jogos sucessivos. Os seres talentosos que inventaram este programa introduziram, por capricho, uma margem de indeterminação, uma pequena fracção de "livre arbítrio", de modo que a máquina, no caso de se encontrar numa situação logística idêntica, não actuará da mesma maneira.

O rival electrónico oculto (cuja inteligência quase humana está contida num pequeno rectângulo que não pesa mais do que uns poucos gramas) é portanto um destro sedutor, sempre à nossa espera, sempre pronto e nunca aborrecido, cortês, despiedado. Chama-nos, invocanos, distrai-nos do nosso trabalho e das nossas leituras, mas não deixa de ser um extra-humano. Na realidade podemos louvar a sua perícia como admiramos a dança de um cavalo de raça Lippizaner, ou as habilidades de uma foca treinada para o circo; podemos até sentir por ele, numa cumplicidade ilícita, um género de compaixão deveras curiosa - pois, no fundo, ele é apenas e exclusivamente um pequeno rectângulo mesmo quando o vemos confrontado com uma situação complicada no tabuleiro de xadrez; um rival de carne e osso, porém, é qualitativamente diferente.

O rival humano estreita-nos laços consanguíneos, mesmo no caso de nos termos conhecido apenas há umas poucas horas. Vemo-nos num frente a frente, medimos as nossas forças mútuas, sabemos que ele é tão dado como nós a fazer descobertas felizes de vez em quando, e a cometer erros inesperados. No fim do jogo, exactamente como no fim de uma vida, ambos podemos confraternizar com a sensação de familiaridade que tem origem na própria rivalidade concretizada no jogo de xadrez, comentar os seus e os nossos erros, formar uma opinião a seu respeito e sentir que ele nos está a fazer a mesma coisa. Ele aprende ("foi uma dura aprendizagem") connnosco, e nós com ele, ao passo que a máquina desde o princípio já sabe tudo e nunca aprende nada. Contudo, podemos ser ainda discípulos face à máquina: mesmo que se trate apenas de aprender a ter um pouco mais de paciência ou de perspicácia, e (porque não?) a teoria dos fechos dos jogos. 


\section{Ex-químico}

0 vínculo que une 0 homem à sua profissão é semelhante ao que o liga à sua pátria; ambos são identicamente complexos, por vezes igualmente ambivalentes, e, em regra geral, apenas se podem compreender por completo quando o vínculo é quebrado: quer em consequência do exillio ou da emigração no caso referente à pátria, quer por reforma quando se deixa de exercer determinado ofício ou profissão.

Não me refiro especificamente ao facto de que este ofício me salvou a vida durante a minha prisão em Auschwitz, nem ainda ao facto de ele ter representado para mim um meio de subsistência não despiciendo durante trinta anos, nem, finalmente, à reforma a que me deu direito. Muito pelo contrário, prefiro descrever outros benefícios que, na minha opinião, adquiri ao longo do exercício das minhas actividades de quími$\mathrm{co}$ : todos estes benefícios relacionam-se em última análise com o meu novo oficio, ou seja, o de escritor. Antes de mais, porém, impỏe-se-nos fazer um esclarecimento. Ser escritor não se pode definir de um modo exacto em função de um ofício, pelo menos, na minha opinião, não deveria ser assim definido. Trata-se de uma actividade criativa que em virtude disso mesmo escapa a uma realidade de horários e prazos, a compromissos com clientes e chefes. Não obstante, 0 acto de escrever é um modo de "produzir" algo, é sobremaneira um modo de efectuar um processo de transformação: isto é, o escritor transforma as suas experiências num molde expressivo que é simultaneamente acessível e atraente ao seu "cliente", ou seja, ao eventual leitor. As experiências (em sentido lato: as experiências existenciais) do escritor constituem portanto a sua matéria prima: o escritor a quem faltam estas experiências escreve como num vazio, e consequentemente parecer-Ihe-á talvez que está realmente a escrever, mas as suas páginas habitam, na verdade, um vácuo. Ora bem, tudo o que vi, vivi, e fiz durante a minha "incarnação" prévia de químico é ainda hoje em dia uma fonte de matéria prima preciosa para a minha vida de escritor, é a matéria prima de acontecimentos que posso narrar, e não só: tal profissão forneceu-me também as emoções fundamentais com que todo o ser humano colide com a matéria (que é um juiz imparcial, imperturbável, sim, mas também inóspito: se o químico se engana face a ela, o castigo subsequente é severo) e com que mede o alcance da sua vitória ou derrota. A derrota por seu lado conduz-nos a uma experiência penosa mas salutar, sern a qual o ser humano não pode chegar a ser adulto responsável. Julgo que todos os meus colegas químicos poderăo confirmar o seguinte: aprendemos mais com os nossos erros do que com as nossas experiências bem sucedidas. Por exemplo: o processo de formular uma hipótese explicativa, de acreditar na sua validade, de nos afeiçoar a ela, de a verificar (sem esquecer a tentação imponente de falsificar os dados e de os ajustar com uns toques discretos) e, no final, descobrir que a hipótese é incorrecta - é um ciclo com que o químico se defronta inúmeras vezes de uma forma "pura". Verdade seja, é um ciclo que é patente em grande número de itinerários humanos. Quem envereda com honestidade por este caminho emerge dele amadurecido.

Há ainda mais benefícios, mais dons que o químico pode oferecer ao escritor. 0 hábito do químico penetrar na matéria, de querer saber a fundo a sua composição e estrutura, de prever as suas propriedades e comportamento, leva-0 a um insight, a um hábito mental que se caracteriza pela clareza e pela concisão e ao desejo ininterrupto de ir além da superfície das coisas. A química é a arte de separar, pesar e diferenciar: estas três actividades são também úteis para qualquer indivíduo que pretende descrever experiências ou dar forma concreta à sua imaginação. Além disso, existe um enorme património de metá- foras que o escritor tem ao seu dispor proveniente da química moderna e antiga que é em grande medida vedado a quem nunca frequentou um laboratório ou uma fábrica. 0 leigo sabe o significado das palavras filtração, cristalização e destilação, mas apenas, digamos, em segunda mão: ignora "a paixão inerente a estes processos", nunca experimentou as emoções que formam parte dos gestos correspondentes a estes actos e por isso não se apercebe da sombra simbólica que estes gestos deitam sobre as coisas. Mesmo ao nivel de simples comparações, o químico dedicado descobre que é munido de uma fonte de riqueza insuspeitada: "tão negro como...", "tão amargo como ...", viscoso, resistente, pesado, fétido, volátil, inerte, inflamável: todas estas qualidades são familiares para o químico, e para cada uma delas ele sabe escolher uma substância afim a um grau de exactidão notável e exemplar. Eu, ex-químico, e que agora me encontraria por assim dizer atrofiado e mal preparado se voltasse a trabalhar num laboratório, quase me envergonho ao saber que sempre que escrevo sirvome deste reportório: sinto que estou a gozar de uma vantagem ilícita face aos meus colegas escritores que não tiveram a minha militância de químico.

Assim, por todas estas razōes, quando um leitor me comunica o seu espanto por eu ter deixado de ser químico para me tornar escritor, sinto-me no direito de the responder que escrevo precisamente porque sou químico: ao tornarme escritor, o meu velho ofício sofreu apenas uma pequena transmutação.

(Primo Levi, in L'Altrui Mestiere, [Os Oficios dos Outros], Einaudi, 1985) (tradução nossa)

"Io credo proprio che per vivere contenti bisogna per forza avere qualche cosa da fare, ma che non sia troppo facile; oppure qualche cosa da desiderare, ma non un desiderio così per aria, qualche cosa che uno abbia la speranza di arrivarci." 